\title{
New Sensitive Technique For Estimation Of Estrogen Receptors
}

\author{
M. I. Aref, N. M. Abomohamed, and A. Shalaby
}

\begin{abstract}
Background: Estrogens play a key role in the human male reproductive system. Estrogen receptors (ERs: $E R \alpha$ and ERß) was detected in germ cells from spermatogonia to spermatozoa.

Objective: Tto evaluate the different estrogen receptors expressions on the sperm in infertile males using a new technique and apply that on infertile patient with varicocele.

Materials and Methods: This study included 200 males, divided into two equal groups. Group1 included fertile males, and group II included infertile males tested according to presence of varicocele with different grades which were classified according to Dubin-Amelar clinical classification of varicocele (1970), $1 \mathrm{~m}$ pellet was examined for the expression of the ER $\alpha$ and ERß using immunocytochemistry stain. The stained sperm was processed in Photoshop program. The estrogen receptors were visualized after magnification and increased resolution in addition using a yellow filter. Percentage of stained sperm with different location in relation to the unstained sperm was counted.

Results: There was a strong expression of ER $\beta$ on the sperm in fertile males while $E R \alpha$ expression very reduced in fertile males and almost absent in all infertile males. Also, there was a statistically significant decrease in both $E R \alpha$ and $\beta$ expression in infertile males than fertile males and in varicocele.

Conclusion: ER technical estimation using immunoassay was better than any other techniques assay because ER could be present, but not function due to dislocation and deposition into wrong position.
\end{abstract}

Index Terms - Estrogen receptors, infertility, receptor expression, sperm production.

\section{INTRODUCTION}

More attention has been given to estrogens receptor in male reproduction after discovery of the fact that disruption of estrogen receptors is associated with male infertility [1]. E2 exerts its action through binding to the classic estrogen receptors $(E R \alpha / E R \beta)$ or to a membrane estrogen receptor such as G protein-coupled estrogen receptor 1 (GPER, GPR30). So, it can trigger both the genomic and nongenomic signaling pathways [2], [3]. Several factors may interfere with these signaling pathway may be general environmental factors or other male factors in the reproductive system [2]-[5].

The expression of estrogen receptors (ER $\alpha$ and ER $\beta$ ) depends on many factors including age, cell type and on testicular cell types]. There is an increased expression of

Published on June 26, 2020

M. I. Aref, Al-Azhar University, Egypt.

N. M. Abomohamed, Al-Azhar University, Egypt.

(corresponding e-mail: nagahimmunologist ${ }^{\circledR}$ yahoo.com)

A. Shalaby, Al-Azhar University, Egypt.
ER $\beta$ on Sertoli cells more than ER $\alpha$ [6]. This switch between ER $\alpha$ and ER $\beta$ expression allows E2 to mediate its effects and regulate proliferation of immature Sertoli cells. Interesting information comes from the study of infertile men suffering from azoospermia [7].

Several studies have tried to detect ERs in sperm to clarify the role of estrogen on sperm The binding sites were located on the midpiece, less on the head and neck, and least on the principal- and end-piece of the tail [7], [8].

The aim of our work was to evaluate the different ERs expressions on the sperm in infertile males, and to correlate between these different expressions by visualization of the receptor location using a new immunocytochemistry stain and processing the capture stained sperm into Photoshop program.

\section{MATERIALS AND METHODS}

This study included 200 males, divided into two equal groups: Group I was fertile, have normal semen analysis according to the World Health Organization (WHO, 2010) guidelines and have normal hormonal profile, and group II was infertile. They were divided according to presence of varicocele (unilateral or bilateral with different grades according to Dubin-Amelar clinical classification of varicocele (1970), and hormonal profile, obesity and hazardous environmental conditions as smoking, heat exposure were excluded in this study.

All participants were subjected to history taking, clinical examination with emphasis on presence and grading of varicocele, testicular size and testicular consistency, inflammatory diseases, swellings, presence of vas deferens previous operations. Doppler ultrasonography for determination of testicular size and sub clinical varicocele was done and body mass index (BMI) was calculated. Hormonal profiles for all participants were done which included FSH, LH, E2, testosterone and prolactin.

Semen samples were obtained by masturbation after 2-5 days of sexual abstinence. Samples were allowed to liquefy for 30 minutes and were examined for seminal parameters according to the WHO (2010) guidelines.

The semen samples were centrifuged at $1000 \mathrm{rpm}$ for 10 minutes then the seminal fluid was discarded. Normal phosphate buffer solution (PBS) replaced the seminal fluid into the sperm pellet. The same steps were done three times for washing the sperms from seminal fluid.

Sperm pellet was divided into three tubes: two tubes were used for examining the expression of the ER $\alpha$ and ER $\beta$ separately and the third one was utilized as a negative control to assess the motility. 


\section{A. Immunocytochemistry assays for estimation of sperm} estrogen $\alpha$ and $\beta$ receptors

1. Primary antibody for ER: Human ER /NR3A1 antibody. "Monoclonal Mouse IgG3" against estrogen- $\alpha$ or $\beta$ receptors. The concentration is " $8-25 \mu \mathrm{g} / \mathrm{mL}$ " $(R \& D$ Systems Tools for Cell Biology Research USA).

2. Secondary antibody for ER $\&$ \& ER $\beta$ : The secondary antibody was a Conjugated Goat Anti-mouse IgG labeled with $10 \mathrm{~nm}$ Colloidal Gold stain. This colloidal gold conjugated antibody was specific for mouse $\operatorname{IgG}$ and showed no cross-reactivity with human/bovine/rabbit IgG (BOSTER BIOLOGICAL TECHNOLOGY Co., Ltd. 3942 B Valley.Ave, Pleasanton, CA, 94566).

B. Immunocytochemistry assay of ER $\alpha$ \& ER $\beta$ expression on the sperm (Guido et al., 2011)

Immunocytochemistry assay of $\mathrm{ER} \alpha$ \& ER $\beta$ expression on the sperm was done by incubating "the primary antibody" for 30 mints to the pellet to attach either ER $\alpha$ or $\mathrm{ER} \beta$, the sample was washed 3 times by PBS to remove non- primary antibody" either anti ER $\alpha$ or anti $\operatorname{ER} \beta$ monoclonal antibodies, detect of ER $\alpha$ or $\beta$ expression on the sperm. The sperm pellet with the primary and secondary antibodies were incubated for 30 minutes, then washed 3 times with PBS to remove nonbonding antibodies and examined under light microscopy. The appearance of a deep brown color due to the colloidal gold stain on the sperm was an indicator of the prescience of $\mathrm{ER} \alpha$ and $\beta$ expressed on the sperm.

Data were analyzed using statistical program SPSS version 25 for windows 8. Qualitative data between groups were expressed with mean $\pm \mathrm{SD}$, Mann -whiting $-\mathrm{U}$ and $\mathrm{t}$ test ANOVA, Correlation co., efficient test followed by LSD post-hoc test. $\mathrm{P}$ value $<0.05$ was considered significant.

\section{RESULTS}

A strong expression of ER- $\beta$ on infertile mail while ER- $\alpha$ expression was very reduced in fertile males and almost absent in all infertile male. Moreover, there was a statistically significant decrease in both ER $\alpha$ \& $\beta$ expression in varicocele. Also, a negative correlation between ER $\beta$ expressions on the sperm compared with a different varicocele grades. There was negative correlation between the progressive sperm motility and different varicocele grades. The correlation between ER $\beta$ expression on the sperm and sperm progressive motility in varicocele group was significantly positive.

TABLE I: MEAN \pm SD OF ER $\alpha \&$ ER $\beta$ EXPRESSION ON THE WHOLE SPERM BETWEEN VARICOCELE AND CONTROL GROUPS (KRUSKAL - WALLIS TEST)

\begin{tabular}{|c|c|c|c|c|}
\hline $\begin{array}{c}\text { Groups } \\
\text { Parameters } \\
\end{array}$ & $\begin{array}{l}\text { Varicocele } \\
\quad(n=71)\end{array}$ & $\begin{array}{l}\text { Control } \\
(\mathrm{n}=100) \\
\end{array}$ & $\mathrm{H}$ & P-value \\
\hline ER $\alpha$ expression $\%$ & $4.85 \pm 2.25$ & $7.61 \pm 2.40$ & 53.687 & $<0.05$ \\
\hline ER $\beta$ expression \% & $56.13 \pm 10.80$ & $83.43 \pm 6.13$ & 121.886 & $<0.05$ \\
\hline
\end{tabular}

TABLE II: Comparison of ER $\alpha \beta$ expression on the sperm head, necktail in different varicocele grades

\begin{tabular}{ccccc}
\hline $\begin{array}{c}\text { Varicocele } \\
\text { groups }\end{array}$ & I $(\mathrm{n}=17)$ & II $(\mathrm{n}=39)$ & III $(\mathrm{n}=15)$ & P-value \\
\hline $\begin{array}{c}\text { ER } \alpha \text { on } \\
\text { sperm head }\end{array}$ & $10.59 \pm 3.91$ & $14.87 \pm 4.05$ & $13.67 \pm 4.42$ & $\begin{array}{c}\text { PI }<0.01^{*} \\
\mathrm{PII}<0.05^{*} \\
\mathrm{PIII}<0.05^{*}\end{array}$ \\
\hline $\begin{array}{c}\text { ER } \beta \% \text { on } \\
\text { sperm neck-tail }\end{array}$ & I $(\mathrm{n}=17)$ & II $(\mathrm{n}=39)$ & III $(\mathrm{n}=15)$ & P-value* \\
\hline Mean \pm SD & $56.76 \pm 12.62$ & $40.51 \pm 7.59$ & $33.0 \pm 6.21$ & $\begin{array}{c}\text { PI }<0.01^{*} \\
\mathrm{PII}<0.05^{*}\end{array}$ \\
\hline \hline
\end{tabular}

F.p: $\mathrm{F}$ and $\mathrm{p}$ values for ANOVA test, Sig. bet. groups was done using Post Hoc Test (LSD).

p1: $p$ value for comparing between Varicocele grade I and Varicocele grade II .

p2: p value for comparing between Varicocele grade I and Varicocele grade III.

p3: p value for comparing between Varicocele grade II and Varicocele grade III.

*: Statistically significant at $\mathrm{p} \leq 0.05$

The correlation between the progressive sperm motility and different varicocele grades was significantly negative correlated. $\quad \mathbf{r}_{\mathrm{s}}=\mathbf{- 0 . 7 6 2}(\mathbf{P}$-value $<\mathbf{0 . 0 0 1})$, the correlation between immotile sperm and different varicocele grades was significantly positive $\mathbf{r}_{\mathrm{s}}=\mathbf{0 . 6 9 0}$, $(\mathbf{P}$-value $<\mathbf{0 . 0 0 1})$ that's to say if the varicocele grade increases the sperm motility decreases (Table III).

The correlation between ER $\alpha$ expression on the sperm neck-tail and sperm progressive motility in varicocele group was significantly positive $\mathbf{r}_{\mathrm{s}}=\mathbf{0 . 7 6 4}(\mathbf{P}<\mathbf{0 . 0 0 1})$, The correlation between ER $\beta$ expression on the sperm neck \& tail and immotile sperm in varicocele group was significantly negative $\mathbf{r}_{\mathrm{s}}=-\mathbf{0 . 6 2 6}(\mathbf{P}<\mathbf{0 . 0 0 1})$ That's to say if ER $\beta$ expression on the sperm neck-tail on varicocele group decreases the progressive sperm motility decreases and the immotile sperm increases (Table III).

TABLE III: Correlation between different grades of sperm motility and different varicocele grades

\begin{tabular}{ccc}
\hline \hline $\begin{array}{c}\text { Varicocele grades } \\
\text { Motility grades }\end{array}$ & $\mathrm{r}_{\mathrm{s}}$ test & P-value \\
\hline $\begin{array}{c}\text { Sperm progressive } \\
\text { motility }\end{array}$ & $-0.762^{*}$ & $<0.001^{*}$ \\
\hline Immotile sperm & 0.690 & $<0.001^{*}$ \\
\hline
\end{tabular}

The Multivariate Linear Regression for progressive motility and ER $\beta$ expression on sperm neck \& tail in different varicocele grades shows that if the varicocele grade increases the ER $\beta$ expression on sperm neck-tail decreases and the sperm progressive motility decreases $\mathbf{t}=\mathbf{4 . 9 4 6}$ for varicocele grades and $\mathbf{t}=\mathbf{5 . 1 1 7}$ for $E R \beta$ expression on sperm neck and tail $\mathrm{p}$ value $<0.001 *$ (Table IV).

TABLE IV: Multivariate Linear regression for sperm progressive motility and ER $\beta$ expression on sperm neck-tail in different varicocele grades

\begin{tabular}{ccccc}
\hline \hline & $\mathrm{B}$ & $\mathrm{SE}$ & Beta & $\mathrm{P}$ \\
\hline Varicocele grades & -5.195 & 1.050 & -0.448 & $<0.001$ \\
\hline $\begin{array}{c}\text { ER } \beta \text { expression on } \\
\text { sperm neck-tail }\end{array}$ & 0.300 & 0.059 & 0.463 & $<0.001$ \\
\hline
\end{tabular}

F: F test (ANOVA). R2: coefficient or regression. B: Unstandardized Coefficients. SE: Estimates Standard error. Beta: Standardized Coefficients. t: t-test of significance. 
The Multivariate Linear Regression for immotile sperm and $\operatorname{ER} \beta$ expression on sperm neck-tail in different varicocele grades shows that if the varicocele grade increases the ER $\beta$ expression on sperm neck \& tail decreases and the immotile sperm increases $\mathbf{t}=\mathbf{4 . 2 4 1}$ for varicocele grades and $\mathbf{t}=\mathbf{2 . 6 6 7}$ for $E R \beta$ expression on sperm neck- tail $\mathrm{p}$ value $<0.0010$ (Table $\mathrm{V}$ ).

TABLE V: Multivariate Linear regression for immotile sperm and ER $\beta$ expression on sperm neck \& tail in different varicocele grades

\begin{tabular}{lccccc}
\hline \hline & $\mathrm{B}$ & $\mathrm{SE}$ & $\mathrm{Beta}$ & $\mathrm{t}$ & $\mathrm{P}$ \\
\hline Varicocele grades & 8.729 & 2.058 & 0.481 & $4.241^{*}$ & $<0.001$ \\
\hline $\begin{array}{c}\text { ER } \beta \text { expression on } \\
\text { sperm neck-tail }\end{array}$ & -0.307 & 0.115 & -0.303 & 2.667 & 0.010 \\
\hline $\mathrm{R}^{2}=0.519, \mathrm{SE}=8.61, \mathrm{~F}=36.753, \mathrm{p}<0.001$ & & &
\end{tabular}

F: F test (ANOVA). R: coefficient or regression. B: Unstandardized Coefficients. SE: Estimates Standard error. Beta: Standardized Coefficients. t: t-test of significance.

A high resolution and magnification immunocytochemistry stained normal sperm. The receptor location are normally in the neck and tail (Fig. 1).

Fig. 2 showed normal estrogen destrepution using 1000 times of magnification and yellow and brown filter, while in Fig. 3 showed abnormal destrepution of estrogen receptors without any felters. Seminal samples were photographic and processed through Photoshop program image I fore increasing both the resolution and magnification for defined the specific location of ER.

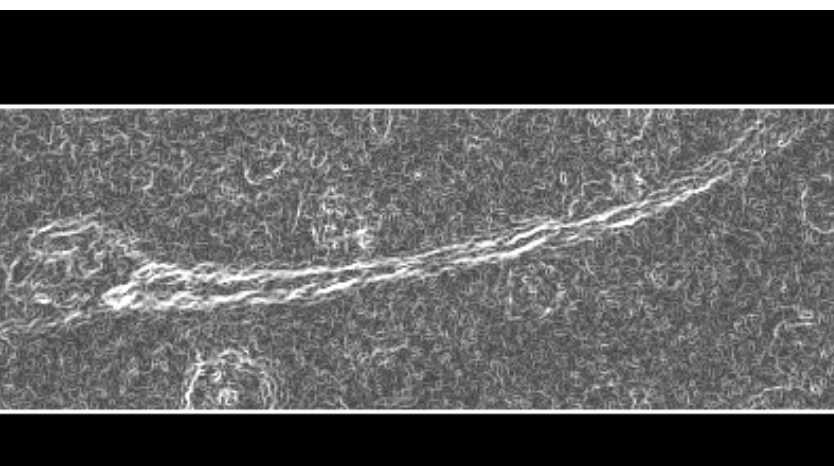

Fig. 1. Normal distribution of estrogen receptor.

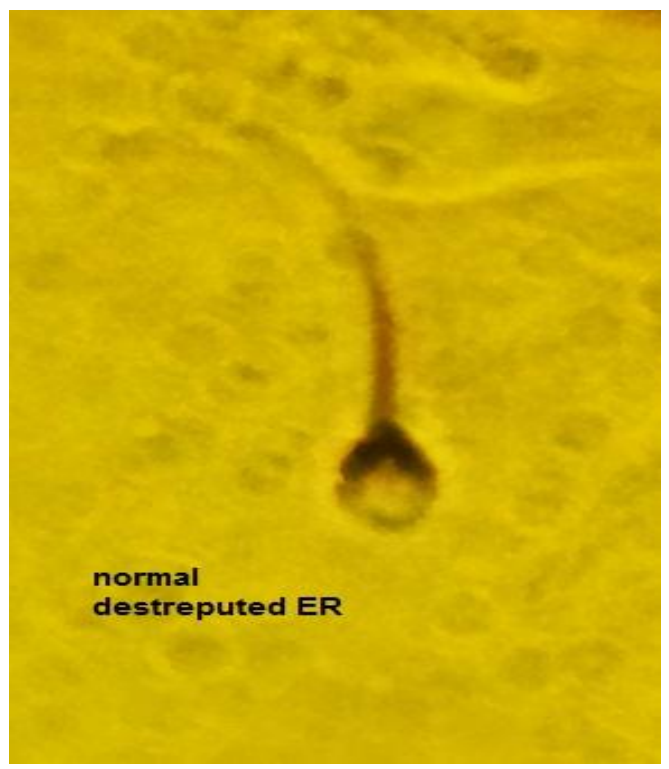

Fig. 2. ER-alfa and beta distribution on normal sperm using yellow and brown filter.

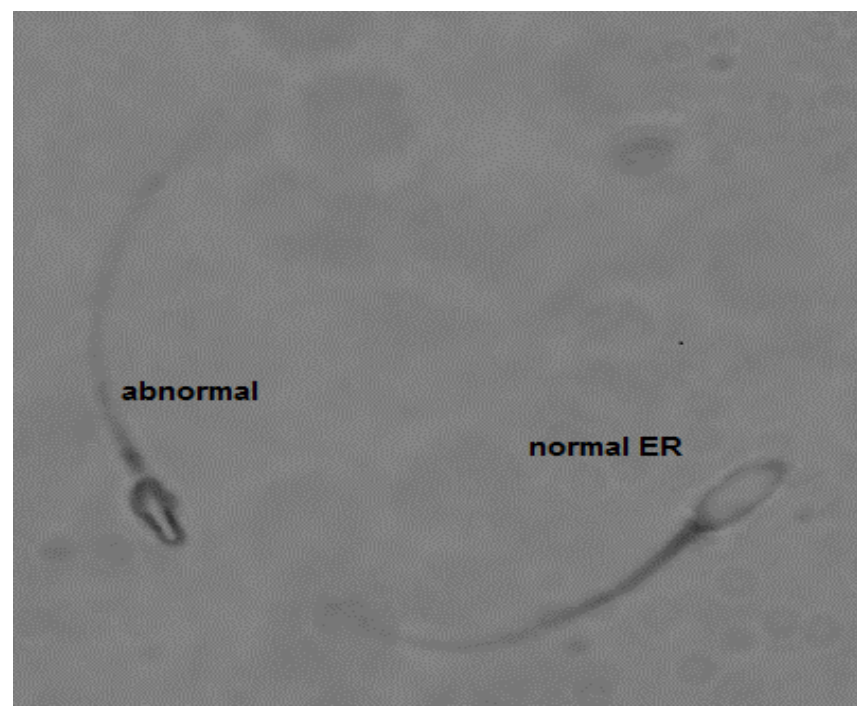

Fig. 3. Destrepution of estrogen receptors.

\section{DISCUSSION}

E2 via different ERs in ejaculated sperm stimulates various sperm functions like motility, capacitation, acrosome reaction and sperm metabolism [10].

The aim of our work was to evaluate the different ERs expressions on the sperm in infertile males and to correlate between these different expressions, and possible causes of male infertility.

Several mechanisms may be involved in the pathophysiology of damaged spermatogenesis induced by varicocele, including hypoxia, renal-adrenal reflux, hormonal dysfunction, autoimmunity, oxidative stress and above all hyperthermia [11]. Increased temperature and stress in general may activate HSPs, which are in turn regulated by HSFs [12]. These proteins have an essential role as molecular chaperones by assisting the correct folding of nascent and stress accumulated misfielded proteins and preventing their aggregation. Thus, HSPs have a protective function, in that they allow cells to survive in otherwise lethal conditions [12], [13].

There were numerous HSPs and HSFs but only 2 groups have evaluated HSPA2 expression in men with varicocele.

This HSP is down-regulated in the ejaculated sperm of men with oligozoospermia, and re-expressed at a higher level 6 months after varicocelectomy [14].

Although adequate comparison with men with oligozoospermia not associated with varicocele is lacking int hese studies, these data suggest that HSPA2 expression may serve as a molecular marker for the acquisition of thermal tolerance in the ejaculated spermatozoa of men with varicocele [14], [15].

Reduced expression of the ERs appears of to be related only to varicocele since itdiscriminates healthy and OAT sperm from those with varicocele.

Therefore, this pattern of ERs expression in varicocele may be considered a molecular marker of the damaging effects of the pathology on spermatogenesis and/or sperm maturation. It was reported that glucocorticoid receptor is rapidly degraded in heat-shocked cells [15], therefore it may also be possible that the increased testicular temperature in varicocele subjects determinates this effect. 
ROS is an independent marker of malefactor infertility and can lead to DNA damage, deformity and damaged plasma membrane integrity in sperm [16]. ROS can also affect normal sperm function and motility by damaging sperm mitochondrial genomes, thereby disturbing mitochondrial function and decreasing energy production [16], [17].

An elevated BMI can impair or arrest spermatogenesis by causing an increase in scrotal temperature. Increased fat distribution in the upper thighs, suprapubic area and scrotum in conjunction with the sedentary lifestyle often associated with obesity can result in increased testicular temperature [18]. Many studies have focused on genital heat stress as a potential cause of impaired semen quality in cases of sedentary occupations, the occurrence of frequent fever and varicocele [18]-[20].

High ROS can produce important destructive effects in tissues by causing alterations in membranes causing an irreversible cellular damage. On the other hand, elevated ROS levels can induce DNA damage in spermatids and in mature sperm [21]-[23].

Previous studies based on animal models have revealed that the most significant consequence of heat stress on the testes is the loss of germ cells via apoptosis, with the mitochondria dependent pathway the key apoptotic pathway involved. Oxidative stress can cause serious injury to the mitochondria, initiating apoptosis and leading ultimately to cell death [24], [25].

The ER technical estimation using immunoassay was added a new factor related to infertility. The redisposition of the ER in sperm head away to the tail makes sperm immotile. The dislocation and deposition of the ER made the receptor non-function other sensitive techniques such as PCR cannot differentiate between function from nonfunction ER, while immunoassay and processing the sperm picture by Photoshop program processing succeeded to exclude function from nonfunction ER.

\section{CONCLUSION}

Immunohystochemistry estimation of ER provide a good protocol for visualizing, positioning and functioning ER. estimation using immunoassay was better than any other techniques assay because ER could be present but not function due to dislocation and deposition into wrong position.

\section{REFERENCES}

[1] Lubahn D.B., Moyer J.S., Golding T.S., Couse J.F., Korach K.S., Smithies O. Alteration of reproductive function but not prenatal sexual development after insertional disruption of the mouse estrogen receptor gene. Proc. Natl. Acad. Sci. USA. 1993;90:11162-11166. doi:10.1073/pnas.90.23.11162.[PMC free article] [PubMed] [CrossRef] [Google Scholar].

[2] Cooper T.G., Noonan E., von Eckardstein S., Auger J., Baker H.W., Behre H.M., Haugen T.B., Kruger T., Wang C., Mbizvo M.T., et al. World health organization reference values for human semen characteristics. Hum. Reprod. Update. 2010;16:231-245. doi: 10.1093/humupd/dmp048. [PubMed] [CrossRef] [Google Scholar].

[3] Schagdarsurengin U., Western P., Steger K., Meinhardt A. 2016 Developmental origins of male subfertility: Role of infection, inflammation, and environmental factors. Semin.Immunopathol.;38:765-781. doi: 10.1007/s00281-016-0576-y. [PubMed] [CrossRef] [Google Scholar].
[4] Bois C., Delalande C., Nurmio M., Parvinen M., Zanatta L., Toppari J., Carreau S. Age- and cell-related gene expression of aromatase and estrogen receptors in the rat testis. J. Mol. Endocrinol. 2010;45:147159. [PubMed] [Cross Ref] [Google Scholar].

[5] Lucas T.F., Lazari M.F., Porto C.S. Differential role of the estrogen receptors ESR1 and ESR2 on the regulation of proteins involved with proliferation and differentiation of sertoli cells from 15-day-old rats. Mol. Cell. Endocrinol. 2014;382:84-96. doi: 10.1016/j.mce.2013.09.015. [PubMed] [CrossRef] [Google Scholar].

[6] Cheng C.Y., Boettcher B., Rose R.J., Kay D.J., Tinneberg H.R. The binding of sex steroids to human spermatozoa.An autoradiographic study. Int. J. Androl. 1981;4:1-17. doi: 10.1111/j.1365 2605.1981.tb00685.x. [PubMed] [CrossRef] [Google Scholar].

[7] Cheng C.Y., Boettcher B., Rose R.J. Lack of cytosol and nuclear estrogen receptors in human spermatozoa. Biochem.Biophys. Res. Commun. 1981;100:840-846. doi: 10.1016/S0006-291X(81)80250-1. [PubMed] [CrossRef] [Google Scholar].

[8] Vander Borght M1, Wyns C2 Fertility and infertility: Definition and epidemiology. ClinBiochem. 2018 Dec;62:2-10. doi: 10.1016/j.clinbiochem.2018.03.012. Epub 2018 Mar 16.

[9] Sirianni R., Chimento A., Ruggiero C., De Luca A., Lappano R., Ando S., Maggiolini M., Pezzi V. The novel estrogen receptor, G protein-coupled receptor 30 , mediates the proliferative effects induced by $17 \beta$-estradiol on mouse spermatogonial GC-1 cell line. Endocrinology. 2008;149:5043-5051. doi: 10.1210/en.2007-1593. [PubMed] [CrossRef] [Google Scholar].

[10] Sheehan M Ramasamy R \&Lamb D. Molecular mechanisms involved in varicocele-associated infertility. Journal of Assisted Reproduction and Genetics March 2014. 31(5) DOI: 10.1007/s10815-014-02009PubMed.

[11] Brigitta D, Bálint C. and Melinda E. Heat-Shock Proteins in Neuroinflammation. Front Pharmacol. 2019; 10: 920.. doi 10.3389/fphar.2019.00920 PubMed.

[12] Lanneau D, Brunet M. Frisan E, Solary E, Fontenay M, Garrido C. 2008Heat shock proteins: essential proteins for apoptosis regulation. J Cell Mol Med. 2008 Jun;12(3):743-61. doi: 10.1111/j.15824934.2008.00273.x. Epub Feb 8.

[13] Mjahed H, Girodon F, Fontenay M, GarridoHeat shock proteins in hematopoietic malignancies. C.Exp Cell Res. 2012 Sep 10; 318(15):1946-58. Epub 2012 May 28.

[14] Vedeckis W.V., Ali M.. Allen H.R.cancer Res. Regulation of glucorticoid receptor proteinand, RNA levels 1989 Apr 15;49(8 Suppl):2295s-2302s.

[15] Agarwal A, Sharma RK, Nallella KP, et al; Reactive oxygen species as an independent marker of male factor infertility.SikkaSCFertilSteril. 2006 Oct;86(4):878-85.

[16] Desai N, Sharma R, Makker K, Sabanegh E, AgarwalA.FertilSteril Physiologic and pathologic levels of reactive oxygen species in neat semen of infertile men. 2009 Nov; 92(5):1626-31. Epub 2008 Oct 19.

[17] Hu X,Zheng Ding Z, Hong Z, et al; Spermatogenesis improved by suppressing the high level of endogenous gonadotropins in idiopathic non-obstructive azoospermia: a case control pilot study Reprod Bio 1Endocrinol. 2018; 16: 91.. doi: 10.1186/s12958-018-0401-7 PMCID PMC6150963 PMID: 30243299.

[18] Hussein A, Ozgok Y, Ross L, Rao P, Niederberger C. BJU Int. 2013 Mar; 111(3 Pt B):E110-4. Epub 2012 Sep 7.

[19] Shiraishi K, Matsuyama H. Endocr J. 2017 Feb 27; 64(2):123-131. Epub 2017 Jan 19.

[20] Macdonald AA, Stewart AW, Farquhar CM. Hum Reprod. 2013 Dec; 28(12):3178-87. Epub 2013 Oct 15.

[21] Ma J, Wu L, Zhou Y, Zhang H, Xiong C, Peng Z, Bao W, Meng T, Liu Y. Hum Reprod. 2019 Jan 1; 34(1):155-162.

[22] Fejes I, Koloszár S, Szöllosi J, Závaczki Z, Pál A. Is semen quality affected by male body fat distribution?.Andrologia. 2005 Oct;37(5):155-9. PMID:16266392 DOI:10.1111/j.14390272.2005.00671.x.

[23] Lu JC, Jing J, Dai JY, Zhao AZ, Yao Q, Fan K, Wang GH, Liang YJ, Chen L, Ge YF, et al.Body mass index, waist-to-hip ratio, waist circumference and waist-to-height ratio cannot predict male semen quality: a report of 1231 subfertile Chinese men.Andrologia. 2015 Nov; 47(9):1047-54. Epub 2014 Nov 22.

[24] Rufus O, James O and Michael A. Male obesity and semen quality: Any association? Int J Reprod Biomed (Yazd). 2018 Apr; 16(4): 285290. PMCID: PMC6004593PMID: 29942937.

[25] Hart K, Tadros NN The role of environmental factors and lifestyle on male reproductive health, the epigenome, and resulting offspring Panminerva Med. 2019 Jun;61(2):187-195. doi: 10.23736/S00310808.18.03531-0. 